\title{
Comparison of antibacterial effects of orthodontic composites containing different nanoparticles on Streptococcus mutans at different times
}

Soghra Yassaei ${ }^{1}$, Ali Nasr ${ }^{1}$, Hengameh Zandi², Mohammad Nima Motallaei ${ }^{1}$

DOI: https://doi.org/10.1590/2177-6709.25.2.052-060.oar

Introduction: Plaque accumulation can cause white spot lesions. Adding nanoparticles to composites can be effective in reducing the number and function of microorganisms. Objective: The aim of this study was to evaluate the antibacterial effects of orthodontic composites containing different nanoparticles on Streptococcus mutans at different times. Methods: Hydroxyapatite, titanium oxides, zinc oxide, copper oxide and silver oxide nanoparticles were prepared at $0.5 \%$ and $1 \%$ weight concentrations. Accordingly, ten study groups and one control group were obtained. Then, 26 composite discs were prepared from each group. Strain of Streptococcus mutans was cultured, and colonies of Streptococcus mutans were counted. Further bacterial culture was swapped onto enriched Mueller-Hinton agar. The composites were placed on the culture medium, and after incubation the diameter of growth inhibition was measured. To investigate the long-term effect of nanoparticles, the colonies were counted at days 3, 15 and 30. Results: The results showed that $1 \%$ copper oxide and $1 \%$ silver oxide significantly reduced the number of bacteria $(p<0.05)$, but there was no significant difference between the other groups and control group $(p>0.05)$. At day three, there was a significant difference between control group and $0.5 \%$ silver oxide, $1 \%$ silver oxide and $1 \%$ copper oxide groups $(p<0.05)$. However, colonies had grown in all groups at day 30 but showed no significant difference with control group $(p>0.05)$.Conclusion: Addition of $1 \%$ copper oxide and $1 \%$ silver oxide has short-term antibacterial effects, so the clinical use of these nanoparticles cannot be justified.

Keywords: Antimicrobial. Antibacterial. Orthodontic composites.

Introdução: $\mathrm{O}$ acúmulo de placa bacteriana pode causar lesões de mancha branca. A adição de nanopartículas nas resinas ortodônticas pode ser eficaz para reduzir o número e a função dos microrganismos. Objetivo: $\mathrm{O}$ objetivo do presente estudo foi avaliar os efeitos antibacterianos contra o Streptococcus mutans, em diferentes intervalos de tempo, de resinas ortodônticas contendo diferentes tipos de nanopartículas. Métodos: Foram criados dez grupos experimentais e um grupo controle contendo nanopartículas de hidroxiapatita, óxido de titânio, óxido de zinco, óxido de cobre e óxido de prata em concentrações de 0,5\% e 1\%. Em seguida, foram preparados 26 discos de resina para cada grupo. Colônias de Streptococcus mutans foram cultivadas e contadas. Posteriormente, as culturas bacterianas foram colocadas em solução de ágar Mueller-Hinton. Os discos de resina foram colocados no meio de cultura e, depois da incubação, mediu-se o diâmetro de inibição do crescimento. Para avaliar os efeitos em longo prazo das nanopartículas, as colônias foram analisadas após 3, 15 e 30 dias. Resultados: Os resultados mostraram que o óxido de cobre a $1 \%$ e o óxido de prata a 1\% reduziram significativamente o número de bactérias $(p<0,05)$, mas não houve diferença estatisticamente significativa entre os outros grupos e o grupo controle $(p>0,05)$. Após 3 dias, houve uma diferença significativa entre o grupo controle e os grupos óxido de prata a $0,5 \%$, óxido de prata a $1 \%$ e óxido de cobre a $1 \%(p<0,05)$. Porém, após 30 dias, as colônias haviam crescido em todos os grupos, sem diferença com o grupo controle $(p>0,05)$. Conclusão: A adição de óxido de cobre a 1\% e óxido de prata a 1\% apresenta efeitos antibacterianos apenas no curto prazo; portanto, o uso clínico dessas nanopartículas não se justifica.

Palavras-chave: Antimicrobianos. Antibacterianos. Resinas ortodônticas.

${ }^{1}$ Shahid Sadoughi University of Medical Sciences, Faculty of Dentistry, Department of Orthodontics (Yazd, Iran).

${ }^{2}$ Shahid Sadoughi University of Medical Sciences, School of Medicine, Department of Microbiology(Yazd, Iran).

» The authors report no commercial, proprietary or financial interest in the products or companies described in this article.
How to cite: Yassaei S, Nasr A, Zandi H, Motallaei MN. Comparison of antibacterial effects of orthodontic composites containing different nanoparticles on Streptococcus mutans at different times. Dental Press J Orthod. 2020 MarApr;25(2):52-60.

DOI: https://doi.org/10.1590/2177-6709.25.2.052-060.oar

Submitted: December 11, 2018 - Revised and accepted: June 05, 2019

Contact address: Mohammad Nima Motallaei

E-mail: nimamotallaei@gmail.com 


\section{INTRODUCTION}

Decalcification of enamel surfaces adjacent to the orthodontic appliances is an important complication associated with orthodontic treatment. ${ }^{1}$ Despite many attempts made in line with patient health education, white spot lesions (WSL) accompanied by fixed orthodontic appliances are still a major clinical problem, and WSLs have been increasing since the advent of bonding brackets. ${ }^{2}$ These spots can apparently lead to patient dissatisfaction after orthodontic treatment. ${ }^{2}$

The first step in preventing WSL is achieving appropriate oral health, including tooth brushing and fluoride toothpaste. For patients with poor cooperation, use of antimicrobial bonding systems around the brackets is helpful. Use of resin-modified glass ionomers (RMGIs), fluoride varnishes and ACP (Amorphous Calcium Phosphate) is also effective in preventing caries. ${ }^{3,4}$ Various studies have shown that more plaque is accumulated around composites compared with other restorative materials or hard dental tissue, which leads to more secondary caries around resin composite restorations. ${ }^{2,5,6}$ This can occur due to surface roughness and the energy released from these materials, which can be caused by the type of resin, size of filler and percentage of filler in the composites. ${ }^{2,5,6}$ Moreover, none of the components of resin composites has bacteriostatic properties. That is why new studies have drawn a special attention to the antibacterial properties of resin composites to reduce the risk of recurrent caries around direct composite restorations. ${ }^{1,2,4}$

Various approaches have been adopted to add antibacterial properties to resin composites and adhesives. The first approach is adding antibacterial materials to the resin matrix that are released over time and inhibit bacterial growth. Examples of this class are addition of materials such as fluoride and chlorhexidine. Although they have initially powerful antibacterial properties, their release does not last for a long time. In addition, the composites having these materials and many others of the same kind have a higher rate of bond failure due to the adverse effects of these materials on their mechanical characteristics. ${ }^{7,8}$ The second approach is adding quaternary ammonium to resin monomers. It seems that this method would be more successful because antibacterial properties last for a longer time. ${ }^{9,10}$ The third approach is adding metal/metal oxides as particles or ions to restorative materials. For many years metals such as silver, gold and zinc have been used as bactericidal and bacteriostatic materials. The antibacterial properties of metals are directly influenced by their surface area. The dimensions of nanoparticles allow more interaction with microorganisms, thereby increasing their antibacterial properties. ${ }^{11}$

Streptococcus mutans is one of the main bacteria responsible for caries. Some studies have proposed silver nanoparticles as the most effective type of metals among metal nanoparticles for preventing the growth of Streptococcus mutans. ${ }^{12,13}$ In addition to silver, many other nanoparticles like hydroxyapatite, chitosan, copper acids, titanium, zinc and silicone dioxide $\left(\mathrm{SiO}_{2}\right)$ have been added to composites and have

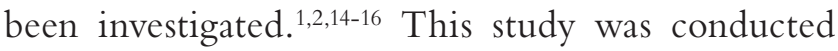
to compare the antibacterial effects of adding different nanoparticles to orthodontic composites on the growth of Streptococcus mutans at different times.

\section{MATERIAL AND METHODS Nanocomposite preparation}

This study was approved by the local Ethical Committee of Shahid Sadoughi University, with the reference number IR.SSU.REC.1396.60, on Feb 2017. In this study, hydroxyapatite (Aldrich), titanium oxides (Sigma-Aldrich), zinc (Aldrich), copper (Aldrich) and silver (Merck) nanoparticles were prepared at $0.5 \%$ and $1 \%$ weight concentrations, measured by a digital scale with four decimal places, and were mixed with light cure orthodontic composite (3M Unitek, Monrovia, California, USA, Transbond XT) in a semi-dark environment using a mixer spatula and a glass slab., ${ }^{2,16}$ Hence, ten study groups and one control group (without nanoparticles) were obtained. For $0.5 \%$ groups (five groups), $0.0065 \mathrm{~g}$ of nanoparticles and $1.2935 \mathrm{~g}$ of composite were used, and for 1\% groups (five groups), $0.013 \mathrm{~g}$ of nanoparticles and $1.287 \mathrm{~g}$ of composite were used. Each group was mixed in a vortex machine (Heidolph, Germany) (Fig 1) for five minutes. To prevent water penetration into the nanoparticle composites, they were placed in previously sterilized capped test tubes, and to prevent light transmission to the composites, the test tubes were insulated with a black Teflon tape and were then placed in Sonicator machine(Elma D-78224) (Fig 2) for 60 minutes. 


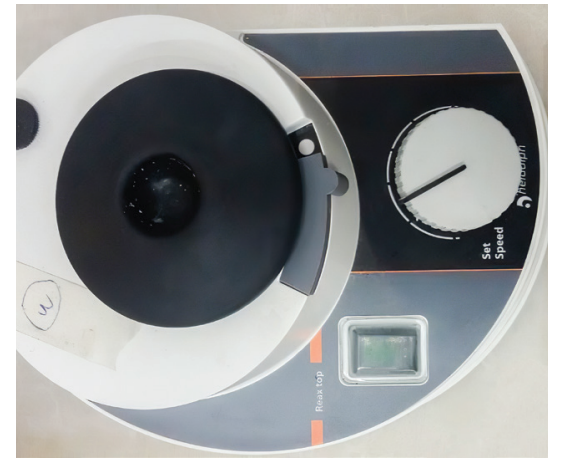

Figure 1 - Vortex machine

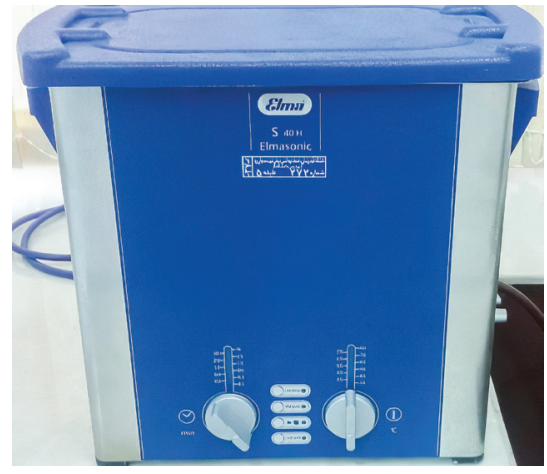

Figure 2 - Sonicator machine.

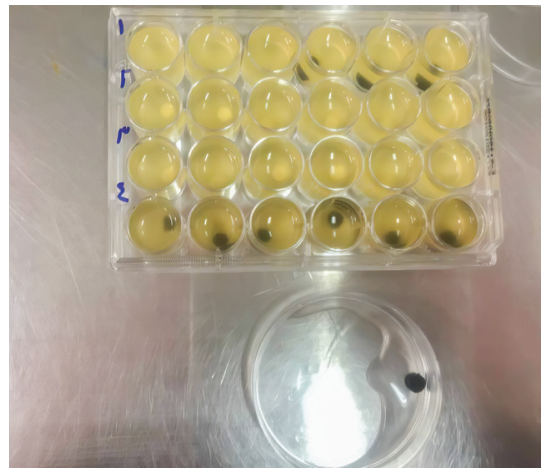

Figure 2-1 - Microplates and washed composite disk after getting out of the well.

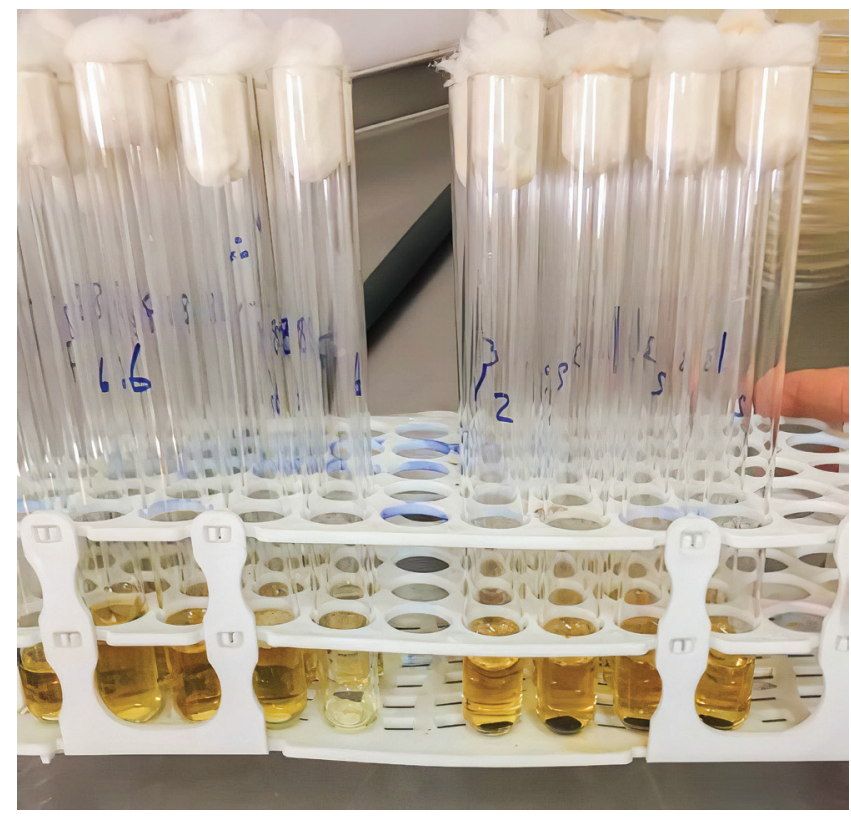

Figure 2-2 - Disks containing nanoparticles in tubes with $5 \mathrm{ml}$ of BHI broth.

To prevent the temperature rise of composites, ice was added to the water in the machine, to keep the temperature stable. Then, 26 composite discs with 6-mm diameter and $1-\mathrm{mm}$ thickness were prepared for each group (ten study groups and one control group). Gamma ray was applied to sterilize the samples.

\section{Antimicrobial test}

To prepare fresh bacterial medium, Streptococcus mutans strain ATCC25175 2,14 was prepared from the Pasteur Institute, was then inoculated onto the culture medium according to the manufacturer's in- structions, and incubated at $37^{\circ} \mathrm{C}$ in a $\mathrm{CO}_{2}$ incubator for $24 \mathrm{~h} .{ }^{14}$ After incubation, the fresh medium was transferred to sterile 5 - $\mathrm{mm}$ test tubes containing physiologic serum, and $0.5 \mathrm{McF}$ arland turbidity standard was prepared.

\section{Biofilm inhibition}

Sterile TSB culture medium was used to determine the adhesion. To this end, a composite sample, $1.5 \mathrm{ml} \mathrm{TSB}$ culture medium and $0.1 \mathrm{ml}$ bacterial suspension were placed in each well. The plates were incubated at $37^{\circ} \mathrm{C}$ for $24 \mathrm{~h}$ in a $\mathrm{CO}_{2}$ incubator, to separate the bacteria attached to the composite (Fig. 2-1). The samples were then transferred to the test tube containing $3 \mathrm{ml}$ physiologic serum and then in an ultrasonic bath at a frequency of $25 \mathrm{~Hz}$ to isolate the biofilm from the composite. Next, $10^{-1}$ to $10^{-4}$ dilutions were prepared from the suspension obtained in sterile physiologic serum. To count the number of bacteria in the prepared dilutions, $0.1 \mathrm{ml}$ of the suspension was inoculated onto the $\mathrm{BHI}$ agar plate, cultured and incubated at $37^{\circ} \mathrm{C}$ in the $\mathrm{CO}_{2}$ incubator for $48 \mathrm{~h}$. Then, the Streptococcus mutans colonies in the plates were counted by a colony counter machine, and $\mathrm{CFU} / \mathrm{ml}$ of the bacteria was determined. Given the dilution coefficient, the number of bacteria in $1 \mathrm{~mL}$ was determined and calculated in $\log 10^{2}$.

\section{Disc agar diffusion (DAD) test}

Next, 0.5 McFarland turbidity standard was prepared from the pure and fresh bacterial culture in the test tube containing physiologic serum. It was then 
swapped onto the Mueller-Hinton agar enriched with $5 \%$ sheep blood and cultured afterwards. The composites containing $0.5 \%$ and $1 \%$ concentrations were cultured onto the culture medium, and after incubation at $37^{\circ} \mathrm{C}$ for $24 \mathrm{~h}$, the diameter ( $\mathrm{mm}$ ) of growth inhibition was measured by a ruler. Penicillin and physiologic serum were used for the sake of control. ${ }^{2}$

\section{Antibacterial properties of eluted components}

To assess the irrigated materials, the discs containing nanoparticle in the $5-\mathrm{ml} \mathrm{BHI}$ broth test tubes were used in a dark environment and temperature of $37^{\circ} \mathrm{C}$ (Fig. 2-2). At days 3, 15 and 30, the discs were removed from the culture medium, and the materials were transferred to sterile test tubes. Then, $50 \mu \mathrm{l} \mathrm{bac-}$ terial suspension with $2.5 \times 10^{5}$ concentration were added to the new tubes and incubated in a shaking incubator for $24 \mathrm{~h}$. It was then transferred from the test tubes to the blood agar, and the number of bacteria was counted. ${ }^{2}$ All culture media used in this study were made by Liofilchem, Italy.

\section{Statistical analysis}

Data were fed into SPSS-22 software, and normality of data was analyzed by Kolmogorov-Smirnov test. Given the normality of data, ANOVA test was used for comparison of the groups and Tukey-HSD test was used for pair comparison of groups. Further, chi-square test was used to compare the study groups at different times.

\section{RESULTS}

This study compared the antibacterial effect of $0.5 \%$ and $1 \%$ concentrations of copper oxide, silver oxide, zinc oxide, hydroxyapatite and titanium oxide nanoparticles. ANOVA test was run to compare the study groups (Table 1). Then, Tukey-HSD test was used for pair comparison of groups. The findings showed a significant difference between 1\% copper oxide group and all other groups, except for 1\% silver oxide group. Further, there was a significant difference between 1\% silver oxide group and all other groups, except $1 \%$ copper oxide group $(p<0.05)$. There were no significant differences between other groups and control group $(p>0.05)$ (Table 2).

Chi-square test was used to compare each group at different times. As shown in Table 3, 0.5\% and 1\% silver oxide showed lack of colony growth at day 15 , but the difference was not statistically significant $(p>0.05)$. In this study, disc diffusion test was used, too. For this purpose, eight samples were included in each group. The mean, standard deviation and diameter of growth inhibition are shown in Table 4. Tukey-HSD test was applied for pair comparison of study groups. As indicated in Table 5, there were significant differences between $1 \%$ copper oxide and $1 \%$ silver oxide groups and other study groups $(p<0.05)$, but no significant difference was found between 1\% silver oxide and $1 \%$ copper oxide groups $(p>0.05)$, which is in line with the results obtained for the inhibitory effect of nanoparticles on the number of colonies (Table 5).

Table 1 - Mean (SD) of Streptococcus mutans colonies in the study groups.

\begin{tabular}{|c|c|c|c|}
\hline Group & $n$ & Mean & SD \\
\hline $\mathrm{CuO} 0,5 \%$ & 6 & 266.67 & 40.825 \\
\hline $\mathrm{ZnO} 0,5 \%$ & 6 & 283.33 & 25.82 \\
\hline HA $1 \%$ & 6 & 300 & 0 \\
\hline $\mathrm{AgO} 0,5 \%$ & 6 & 275 & 27.386 \\
\hline HA 0,5\% & 6 & 300 & 0 \\
\hline Control & 6 & 300 & 0 \\
\hline $\mathrm{CuO} 1 \%$ & 6 & 158.33 & 58.452 \\
\hline $\mathrm{TiO}_{2} 1 \%$ & 6 & 241.67 & 66.458 \\
\hline $\mathrm{AgO} 1 \%$ & 6 & 133.33 & 68.313 \\
\hline $\mathrm{TiO}_{2} 0,5 \%$ & 6 & 300 & 0 \\
\hline $\mathrm{ZnO} 1 \%$ & 6 & 291.67 & 20.412 \\
\hline Total & 66 & 259.09 & 66.742 \\
\hline
\end{tabular}


Table 2 - Comparison of mean difference between study groups in biofilm-inhibition test, using Tukey-HSD test.

\begin{tabular}{|c|c|c|c|c|c|c|c|c|c|c|c|}
\hline Groups & $\begin{array}{c}\text { Zno } \\
1 \%\end{array}$ & $\begin{array}{l}\mathrm{THO}_{2} \\
0.5 \%\end{array}$ & $\begin{array}{c}\text { AgO } \\
1 \%\end{array}$ & $\begin{array}{l}\mathrm{THO}_{2} \\
1 \%\end{array}$ & $\begin{array}{c}\text { Cuo } \\
1 \%\end{array}$ & Control & $\begin{array}{c}\text { HA } \\
0.5 \%\end{array}$ & $\begin{array}{l}\text { AgO } \\
0.5 \%\end{array}$ & $\begin{array}{l}\mathrm{HA} \\
1 \%\end{array}$ & $\begin{array}{l}\text { Zno } \\
0.5 \%\end{array}$ & $\begin{array}{l}\text { CuO } \\
0.5 \%\end{array}$ \\
\hline $\mathrm{CuO} 0.5 \%$ & -25 & -33.3 & 133.3 & 25 & 108.3 & 33.3 & 33.3 & -8.3 & 33.3 & 16.6 & \\
\hline$p$-valor & 0.987 & 0.909 & $<0.001$ & 0.987 & $<0.001$ & 0.909 & 0.909 & 1 & 0.909 & 1 & \\
\hline $\mathrm{ZnO} 0.5 \%$ & -8.3 & -16.6 & 150 & 41.6 & 125 & -16.6 & -16.6 & 8.3 & -16.6 & & 16.6 \\
\hline$p$-valor & 1 & 1 & $<0.001$ & 0.719 & $<0.001$ & 1 & 1 & 1 & 1 & & 1 \\
\hline HA $1 \%$ & 8.3 & 0 & 166.6 & 85.3 & 141.6 & 0 & 0 & 25 & \multirow{2}{*}{ - } & -16.6 & 33.3 \\
\hline$p$-valor & 1 & 1 & $<0.001$ & 0.25 & $<0.001$ & 1 & 1 & 0.987 & & 1 & 0.909 \\
\hline $\mathrm{AgO} 0.5 \%$ & -16.6 & -25 & 141.6 & 33.3 & 116.6 & -25 & -25 & \multirow{2}{*}{-} & 25 & 8.3 & -8.3 \\
\hline$p$-valor & 1 & 0.987 & $<0.001$ & 0.909 & $<0.001$ & 0.987 & 0.987 & & 0.987 & 1 & 1 \\
\hline HA 0.5\% & 8.3 & 0 & 166.6 & 58.3 & 141.6 & 0 & \multirow{2}{*}{-} & -25 & 0 & -16.6 & 33.3 \\
\hline$p$-valor & 1 & 1 & $<0.001$ & 0.25 & $<0.001$ & 1 & & 0.987 & 1 & 1 & 0.909 \\
\hline Control & 8.3 & 0 & 166.6 & 58.3 & 141.6 & \multirow{2}{*}{ - } & 0 & -25 & 0 & -16.6 & 33.3 \\
\hline$p$-valor & 1 & 1 & $<0.001$ & 0.25 & $<0.001$ & & 1 & 0.987 & 1 & 1 & 0.909 \\
\hline $\mathrm{CuO} 1 \%$ & 133.3 & -141.6 & 25 & -83.3 & \multirow{2}{*}{-} & 141.6 & 141.6 & 116.6 & 141.6 & 125 & 108.3 \\
\hline$p$-valor & $<0.001$ & $<0.001$ & 0.987 & 0.015 & & $<0.001$ & $<0.001$ & $<0.001$ & $<0.001$ & $<0.001$ & $<0.001$ \\
\hline $\mathrm{TiO}_{2} 1 \%$ & -50 & -58.3 & 108.3 & \multirow{2}{*}{-} & -83.3 & 58.3 & 58.3 & 33.3 & 58.3 & 41.6 & 25 \\
\hline p-valor & 0.468 & 0.25 & $<0.001$ & & 0.015 & 0.25 & 0.25 & 0.909 & 0.25 & 0.719 & 0.987 \\
\hline $\mathrm{AgO} 1 \%$ & 158.3 & -166.6 & \multirow{2}{*}{-} & 108.3 & 25 & 166.6 & 166.6 & 141.6 & 166.6 & 150 & 133.3 \\
\hline$p$-valor & $<0.001$ & $<0.001$ & & $<0.001$ & 0.987 & $<0.001$ & $<0.001$ & $<0.001$ & $<0.001$ & $<0.001$ & $<0.001$ \\
\hline $\mathrm{TiO}_{2}$ 0.5\% & 8.3 & \multirow[t]{2}{*}{-} & -166.6 & -58.3 & -141.6 & 0 & 0 & -25 & 0 & -16.6 & -33.3 \\
\hline p-valor & 1 & & $<0.001$ & 0.25 & $<0.001$ & 1 & 1 & 0.987 & 1 & 1 & 0.909 \\
\hline $\mathrm{ZnO} 1 \%$ & \multirow{2}{*}{-} & 8.3 & 158.3 & -50 & 133.3 & 8.3 & 8.3 & -16.6 & 8.3 & -8.3 & -25 \\
\hline p-valor & & 1 & $<0.001$ & 0.468 & $<0.001$ & 1 & 1 & 1 & 1 & 1 & 0.987 \\
\hline
\end{tabular}

Table 3 - Comparison of study groups at days 3, 15 and 30

\begin{tabular}{|c|c|c|c|c|c|c|}
\hline & \multicolumn{6}{|c|}{ Day } \\
\hline & \multicolumn{2}{|c|}{3} & \multicolumn{2}{|c|}{15} & \multicolumn{2}{|c|}{30} \\
\hline & Success & Repeat & Success & Repeat & Success & Repeat \\
\hline & percentage & number & percentage & number & percentage & number \\
\hline CuO 0.50\% & 0 & 3 & 0 & 3 & 0 & 3 \\
\hline $\mathrm{ZnO} 0.50 \%$ & 0 & 3 & 0 & 3 & 0 & 3 \\
\hline HA $1 \%$ & 0 & 3 & 0 & 3 & 0 & 3 \\
\hline $\mathrm{AgO} 0.50 \%$ & 0 & 3 & 33.3 & 3 & 66.7 & 3 \\
\hline HA $0.5 \%$ & 0 & 3 & 0 & 3 & 0 & 3 \\
\hline Control & 0 & 3 & 0 & 3 & 66.7 & 3 \\
\hline CuO 1\% & 0 & 3 & 0 & 3 & 0 & 3 \\
\hline $\mathrm{TiO}_{2} 1 \%$ & 0 & 3 & 0 & 3 & 0 & 3 \\
\hline $\mathrm{AgO} 1 \%$ & 0 & 3 & 66.7 & 3 & 100 & 3 \\
\hline $\mathrm{TiO}_{2}, 0.5 \%$ & 0 & 3 & 0 & 3 & 0 & 3 \\
\hline $\mathrm{ZnO} 1 \%$ & 0 & 3 & 0 & 3 & 0 & 3 \\
\hline
\end{tabular}


Table 4 - Mean (SD) of the zone of inhibition diameter in the study groups.

\begin{tabular}{|c|c|c|c|}
\hline Groups & $n$ & Mean & SD \\
\hline $\mathrm{CuO} 0.5 \%$ & 8 & 7.5 & 0.756 \\
\hline $\mathrm{ZnO} 0.5 \%$ & 8 & 6 & 0 \\
\hline HA $1 \%$ & 8 & 6 & 0 \\
\hline $\mathrm{AgO} 0.5 \%$ & 8 & 8.5 & 0.535 \\
\hline HA $0.5 \%$ & 8 & 6 & 0 \\
\hline Control & 8 & 6 & 0 \\
\hline CuO $1 \%$ & 8 & 8 & 0.535 \\
\hline $\mathrm{TiO}_{2}, 1 \%$ & 8 & 6 & 0 \\
\hline $\mathrm{AgO} 1 \%$ & 8 & 9.13 & 0.641 \\
\hline $\mathrm{TiO}_{2} 0.5 \%$ & 8 & 6 & 0 \\
\hline $\mathrm{ZnO} 1 \%$ & 8 & 6 & 0 \\
\hline Total & 88 & 6.83 & 1.215 \\
\hline
\end{tabular}

Table 5 - Comparison of mean difference between study groups in the zone of inhibition diameter, using Tukey-HSD test.

\begin{tabular}{|c|c|c|c|c|c|c|c|c|c|c|c|}
\hline Groups & $\begin{array}{c}\text { Zno } \\
1 \%\end{array}$ & $\begin{array}{l}\mathrm{THO}_{2} \\
0.5 \%\end{array}$ & $\begin{array}{c}\text { AgO } \\
1 \%\end{array}$ & $\begin{array}{c}\mathrm{THO}_{2} \\
1 \%\end{array}$ & $\begin{array}{c}\text { CuO } \\
1 \%\end{array}$ & Control & $\begin{array}{c}\text { HA } \\
0.50 \%\end{array}$ & $\begin{array}{l}\text { Ag० } \\
0.5 \%\end{array}$ & $\begin{array}{l}\text { HA } \\
1 \%\end{array}$ & $\begin{array}{c}\text { Zno } \\
0.50 \%\end{array}$ & $\begin{array}{c}\text { Cu० } \\
0.50 \%\end{array}$ \\
\hline $\mathrm{CuO} 0.5 \%$ & 1.5 & 1.5 & -1.625 & 1.5 & -0.5 & 1.5 & 1.5 & -1 & 1.5 & 1.5 & \\
\hline$p$-valor & $<0.001$ & $<0.001$ & $<0.001$ & $<0.001$ & 0.237 & $<0.001$ & $<0.001$ & $<0.001$ & $<0.001$ & $<0.001$ & \\
\hline $\mathrm{ZnO} 0.5 \%$ & 0 & 0 & -3.125 & 0 & -2 & 0 & 0 & 2.5 & 0 & \multirow{2}{*}{--} & 1.5 \\
\hline p-valor & 1 & 1 & $<0.001$ & 1 & $<0.001$ & 1 & 1 & $<0.001$ & 1 & & $<0.001$ \\
\hline HA $1 \%$ & 0 & 0 & -3.125 & 0 & -2 & 0 & 0 & -2.5 & \multirow{2}{*}{--} & 0 & 1.5 \\
\hline$p$-valor & 1 & 1 & $<0.001$ & 1 & $<0.001$ & 1 & 1 & $<0.001$ & & 1 & $<0.001$ \\
\hline $\mathrm{Ag} \bigcirc 0.5 \%$ & 2.5 & 2.5 & -0.625 & 2.5 & 0.5 & 2.5 & 2.5 & \multirow{2}{*}{--} & -2.5 & 2.5 & -1 \\
\hline p-valor & $<0.001$ & $<0.001$ & 0.049 & $<0.001$ & 0.237 & $<0.001$ & $<0.001$ & & $<0.001$ & $<0.001$ & $<0.001$ \\
\hline HA 0.5\% & 0 & 0 & 1.2503 & 0 & -2 & 0 & \multirow{2}{*}{--} & 2.5 & 0 & 0 & 1.5 \\
\hline$p$-valor & $<0.001$ & 1 & $<0.001$ & 1 & $<0.001$ & 1 & & $<0.001$ & 1 & 1 & $<0.001$ \\
\hline Control & 0 & 0 & -3.125 & 0 & -2 & \multirow{2}{*}{--} & 0 & 2.5 & 0 & 0 & 1.5 \\
\hline$p$-valor & 1 & 1 & $<0.001$ & 1 & $<0.001$ & & 1 & $<0.001$ & 1 & 1 & $<0.001$ \\
\hline CuO 1\% & 2 & 2 & -1.125 & 2 & \multirow{2}{*}{--} & -2 & -2 & 0.5 & -2 & -2 & -0.5 \\
\hline$p$-valor & $<0.001$ & $<0.001$ & $<0.001$ & $<0.001$ & & $<0.001$ & $<0.001$ & 0.237 & $<0.001$ & $<0.001$ & 0.237 \\
\hline $\mathrm{TiO}_{2} 1 \%$ & 0 & 0 & -3.125 & \multirow{2}{*}{--} & 2 & 0 & 0 & 2.5 & 0 & 0 & 1.5 \\
\hline$p$-valor & 1 & 1 & $<0.001$ & & $<0.001$ & 1 & 1 & $<0.001$ & 1 & 1 & $<0.001$ \\
\hline $\mathrm{AgO} 1 \%$ & 3.125 & 3.125 & \multirow{2}{*}{-} & -3.125 & -1.125 & -3.125 & 1.2503 & -0.625 & -3.125 & -3.125 & -1.625 \\
\hline$p$-valor & $<0.001$ & $<0.001$ & & $<0.001$ & $<0.001$ & $<0.001$ & $<0.001$ & 0.049 & $<0.001$ & $<0.001$ & $<0.001$ \\
\hline $\mathrm{TiO}_{2}$ 0.5\% & 0 & \multirow{2}{*}{--} & 3.125 & 0 & 2 & 0 & 0 & 2.5 & 0 & 0 & 1.5 \\
\hline$p$-valor & 1 & & $<0.001$ & 1 & $<0.001$ & 1 & 1 & $<0.001$ & 1 & 1 & $<0.001$ \\
\hline $\mathrm{ZnO} 1 \%$ & \multirow{2}{*}{-- } & 0 & 3.125 & 0 & 2 & 0 & 0 & 2.5 & 0 & 0 & 1.5 \\
\hline p-valor & & 1 & $<0.001$ & 1 & $<0.001$ & 1 & 1 & $<0.001$ & 1 & 1 & $<0.001$ \\
\hline
\end{tabular}




\section{DISCUSSION}

In the present study, copper oxide, silver oxide, zinc oxide, hydroxyapatite and titanium oxide nanoparticles were added to composites at $0.5 \%$ and $1 \%$ concentrations, and antimicrobial effects of the composites containing these nanoparticles on Streptococcus mutans were compared at different times. Comparison of the effects of these nanoparticles at different concentrations at different times in one study is one of the advantages of the present study. Some studies have used higher concentrations of nanoparticles. ${ }^{17,18}$ The highest concentration of nanoparticles used in the current study was 1\%. Higher concentrations may cause toxicity and esthetic problems in cases like silver oxide. In addition, studies have shown that use of nanoparticles such as 1\% zinc oxide and silver oxide can significantly increase antibacterial effects without reducing mechanical properties like shear strength, shear coefficient, compressive strength and shear bond strength of resin composites. ${ }^{18-20}$ Use of low concentrations of metal nanoparticles can decrease severe discoloration and esthetic problems of resin composites. ${ }^{14}$ The results of the present study indicated a significant difference between 1\% copper oxide and silver oxide and other study groups, including control group. However, no significant difference was found between 1\% copper oxide and silver oxide nanoparticles. It should be noted that the curing time increased in copper oxide and silver oxide groups, which could be due to light absorption by these nanoparticles due to their black color. Both copper and silver oxides have been coated on and incorporated with other materials. ${ }^{21}$ Copper oxide is cheaper and chemically and physically more stable than silver. Copper oxide nanoparticles in suspensions have shown extensive antimicrobial effects against a wide range of pathogen bacteria. One of the most important mechanisms of antimicrobial effects of nanoparticles is destruction of the membrane of microorganisms. Since Streptococcus mutans is a gram-positive bacterium, copper nanoparticles seem to affect this bacterium. ${ }^{12,21}$

Some studies suggested the incorporation of copper oxide nanoparticles with polymers, the same as silver. ${ }^{22,23}$ Argueta-Figueroa et al. ${ }^{24}$ conducted a study to investigate the antimicrobial effects of composites containing copper nanoparticles. They added nanoparticles at weight concentrations of $0.0100 \%, 0.0075 \%$ and $0.0050 \%$ and concluded that the composites containing copper nanoparticles had a significant inhibitory effect on the studied microbes. Poosti et al. ${ }^{4}$ carried out a study on the antibacterial effects of copper oxide and zinc oxide nanoparticles coated on orthodontic brackets and reported that copper and copper-zinc nanoparticles had antimicrobial effect on Streptococcus mutans. Moreover, Toodehzaeim et al. ${ }^{16}$ studied the antimicrobial effects of adhesives containing copper oxide nanoparticles and reported antimicrobial effects for these materials. Hence, the results of the present study are in agreement with those of Argueta-Figueroa et al. ${ }^{24}$ and Toodehzaeim et al. ${ }^{16}$

Silver oxide was a nanoparticle that showed a significant effect in inhibition of Streptococcus mutans growth in the current study. Silver oxide has a good antibacterial activity and its surface/volume ratio and antibacterial activity are increased when it is converted to nanoparticle. This substance has a potent cytotoxic effect on a wide range of microorganisms in both ionic and metallic forms. Several studies have reported the cytotoxicity of silver nanoparticles on the fungi, protozoa, a number of viruses and gram-positive and -negative bacteria like Streptococcus mutans, lactobacillus, Escherichia coli and Staphylococcus aureus, as well as antibacterial and bactericidal properties. Since silver affects Streptococcus in oral cavity and periodontal pathogens and inhibits bacterial adhesion to the surfaces as well as biofilm formation, it can be added to the dental materials as a useful antibacterial additive. ${ }^{3,12,13,15}$ Some studies have reported the antibacterial activity of silver nanoparticles in toothcolored restoration against oral Streptococcus. ${ }^{12,13}$

It is believed that silver ions interfere with three major components of the bacterial cell wall, including peptidoglycan cell wall, plasma membrane and bacterial DNA, as well as bacterial proteins, especially the enzymes involved in vital cell processes such as electron transfer chain, and cause cell death. It has also been reported that the silver ions lyse bacterial cell wall. ${ }^{12}$ Yet, there are concerns about silver toxicity which have limited the use of silver in human being, so they need to be taken into account. ${ }^{25}$ Moreover, nanotechnology has made possible the production of silver nanoparticles with a smaller size and higher surface/volume ratio, which can produce higher antimicrobial effect and less toxicity in human. ${ }^{15}$

Kasraei et $a l .{ }^{26}$ carried out a study on the antimicrobial effects of resin composites containing silver nanoparticles on Streptococcus mutans and lactobacillus. The findings showed the silver nanoparticle composites had a higher antimicrobial effect, compared to 
control group, confirming the results of the present study. The review study by Bapat et al. ${ }^{12}$ proposed silver nanoparticles as very good nanoparticles to be added to different materials due to having excellent antimicrobial properties and not affecting the mechanical properties of the materials. ${ }^{12}$ Another study by Chambers et al. ${ }^{27}$ showed that adding $\mathrm{Ag}-\mathrm{TiO}_{2}$ to orthodontic polymers induced antimicrobial effects.

Another nanoparticle studied in the present research was titanium oxide. The results showed 1\% titanium oxide reduced the number of colonies but presented no significant difference with control group, which was in contrast with the findings of the study by Poosti et al. ${ }^{4}$ It should be noted that spontaneous curing of composite was observed in titanium oxide group. Mirhashemi et $a l .{ }^{28}$ conducted a study on the antimicrobial effects of adding zinc oxide and chitosan nanoparticles on orthodontic composites. The antimicrobial effects of these nanoparticles on the growth of Streptococcus mutans, Streptococcus sanguinis and Lactobacillus acidophilus as both planktonic and biofilm on the composites were investigated in four groups. Three groups with 1\%, 5\% and $10 \%$ concentrations of nanoparticles and one control group were also considered. The findings showed that nanoparticles could add significant antimicrobial effects to the composite only at $10 \%$ concentration. In the study of Mirhashemi et al. ${ }^{28}$, higher concentrations such as 5 and 10\% were used. In the given study, zinc oxide showed an inhibitory diameter of zero even at $10 \%$ concentration. Poosti et $\mathrm{al} .{ }^{4}$ performed a study on the antibacterial effects of copper oxide and zinc oxide nanoparticles coated on orthodontic brackets, and concluded that the antibacterial effects of copper and copper-zinc nanoparticles on Streptococcus mutans were higher than those of zinc nanoparticle. In the present study as well, there was no significant difference between the control and zinc oxide groups.

Abdulkareem et al. ${ }^{29}$ investigated the anti-biofilm effect of hydroxyapatite and zinc oxide nanoparticles and found that use of hydroxyapatite was not effective. In the present study, there was no significant difference between hydroxyapatite and control groups, and hydroxyapatite indicated a lower effect than zinc. Hence, the results of the present study are in agreement with those of Abdulkareem et al. ${ }^{29}$, Mirhashemi et al. ${ }^{28}$ and Poosti et al. ${ }^{4}$

Considering the long-term presence of these composites in the patients, it is necessary to consider the long-term effect of their antibacterial properties to justify their clinical application. A significant point in this study was the analysis of antibacterial effect of these nanoparticles at days 3, 15 and 30, in order to compare their long-term effects, something which has not been investigated in similar studies. ${ }^{14,24,26}$ However, the results of the present study indicated that $1 \%$ copper oxide and $1 \%$ silver oxide and $0.5 \%$ silver oxide groups showed antibacterial effects at day 3. Also, 0.5 and $1 \%$ silver oxide nanoparticles showed lack of colony growth at day 15 , but there was no statistically significant difference between them. However, none of the study groups showed antibacterial effects at day 30 . This questions the clinical use of these nanoparticles. Furthermore, Poosti et al. ${ }^{4}$ studied the 30-day effect of $1 \%$ titanium oxide and reported its long-term effects during this period. But the present research showed none of these effects in all periods. Thus, further studies are needed to determine the periods in which composite nanoparticles exert their effects. In addition, some important issues like long-term clinical application and bond strength of brackets to these composites should be explored.

\section{CONCLUSION}

Adding 1\% copper oxide and 1\% silver oxide provides short-term antibacterial effects, which, however, does not justify their clinical use.

\section{Authors contribution (ORCID ${ }^{(D)}$ )}

Soghra Yasseai (SY): 0000-0001-5096-1107 ${ }^{\text {(D) }}$

Ali Nasr (AN): 0000-0003-0977-7994

Hengameh Zandi (HZ): 0000-0002-8323-2370 (1)

Mohammad N. M. (MNM): 0000-0002-9153-5195

Conception or design of the study: SY. Data acquisition, analysis or interpretation: SY, AN, HZ, MNM. Writing the article: MNM. Critical revision of the article: SY, AN, HZ, MNM. Final approval of the article: SY, AN, HZ, MNM. Obtained funding: AN. Overall responsibility: SY; MNM. 
1. Behnaz M. Dalaie K, Mirmohammadsadeghi H, Salehi H, Rakhshan V. Aslani F. Shear bond strength and adhesive remnant index of orthodontic brackets bonded to enamel using adhesive systems mixed with TiO2 nanoparticles. Dental Press J Orthod. 2018;23(4):43.e1-7.

2. Sodagar A, Akhoundi MSA, Bahador A, Jalali YF, Behzadi Z, Elhaminejad $\mathrm{F}$, et al. Effect of TiO2 nanoparticles incorporation on antibacterial properties and shear bond strength of dental composite used in Orthodontics. Dental Press J Orthod. 2017:22(5):67-74.

3. Ahn SJ, Lee SJ, Kook JK, Lim BS. Experimental antimicrobial orthodontic adhesives using nanofillers and silver nanoparticles. Dent Mater. 2009;25(2):206-13

4. Poosti M, Ramazanzadeh B, Zebarjad M, Javadzadeh P, Naderinasab M, Shakeri MT. Shear bond strength and antibacterial effects of orthodontic composite containing $\mathrm{TiO} 2$ nanoparticles. Eur J Orthod. 2013:35(5):676-9

5. Aydin Sevinc B, Hanley L. Antibacterial activity of dental composites containing zinc oxide nanoparticles. J Biomed Mater Res B Appl Biomater. 2010:94(1):22-31

6. Sehgal V, Shetty VS, Mogra S, Bhat G, Eipe M, Jacob S, et al. Evaluation of antimicrobial and physical properties of orthodontic composite resin modified by addition of antimicrobial agents--an in-vitro study. Am J Orthod Dentofacial Orthop. 2007;131(4):525-9.

7. Leung D, Spratt DA, Pratten J, Gulabivala K, Mordan NJ, Young AM Chlorhexidine-releasing methacrylate dental composite materials. Biomaterials. 2005:26(34):7145-53.

8. Wiegand A, Buchalla W, Attin T. Review on fluoride-releasing restorative materials--fluoride release and uptake characteristics, antibacterial activity and influence on caries formation. Dent Mater. 2007:23(3):343-62.

9. Melo MA, Cheng L, Weir MD, Hsia RC, Rodrigues LK, Xu HH. Novel dental adhesive containing antibacterial agents and calcium phosphate nanoparticles. J Biomed Mater Res B Appl Biomater. 2013;101(4):620-9.

10. Xu X, Wang Y, Liao S, Wen ZT, Fan Y. Synthesis and characterization of antibacterial dental monomers and composites. JBiomed Mater Res B Appl Biomater. 2012;100(4):1151-62

11. Phan TN, Buckner T, Sheng J, Baldeck JD, Marquis RE. Physiologic actions of zinc related to inhibition of acid and alkali production by oral streptococci in suspensions and biofilms. Oral Microbiol Immunol. 2004:19(1):31-8

12. Bapat RA, Chaubal TV, Joshi CP, Bapat PR, Choudhury H, Pandey M, et al. An overview of application of silver nanoparticles for biomaterials in dentistry. Mater Sci Eng C Mater Biol Appl. 2018 Oct 1;91:881-98.

13. Hernandez-SierraJF, Ruiz F, Pena DC, Martinez-Gutierrez F, Martinez AE, Guillen Ade J, et al. The antimicrobial sensitivity of Streptococcus mutans to nanoparticles of silver, zinc oxide, and gold. Nanomedicine. 2008:4(3):237-40

14. Kim JS, Shin DH. Inhibitory effect on Streptococcus mutans and mechanical properties of the chitosan containing composite resin. Restor Dent Endod. 2013;38(1):36-42.
15. Monteiro DR, Gorup LF, Takamiya AS, Ruvollo-Filho AC, Camargo ER, Barbosa DB. The growing importance of materials that prevent microbial adhesion: antimicrobial effect of medical devices containing silver. Int J Antimicrob Agents. 2009:34(2):103-10

16. Toodehzaeim MH, Zandi H, Meshkani H, Hosseinzadeh Firouzabadi A The effect of $\mathrm{CuO}$ nanoparticles on antimicrobial effects and shear bond strength of orthodontic adhesives. J Dent (Shiraz). 2018;19(1):1-5

17. Spencer CG, Campbell PM, Buschang PH, Cai J, Honeyman AL. Antimicrobial effects of zinc oxide in an orthodontic bonding agent. Angle Orthod. 2009:79(2):317-22.

18. Yoshida K, Tanagawa M, Matsumoto S, Yamada T, Atsuta M. Antibacterial activity of resin composites with silver-containing materials. Eur J Oral Sci. 1999 Aug:107(4):290-6.

19. Tanagawa M, Yoshida K, Matsumoto S, Yamada T, Atsuta M. Inhibitory effect of antibacterial resin composite against Streptococcus mutans. Caries Res. 1999:33(5):366-71.

20. Tavassoli Hojati S, Alaghemand H, Hamze F, Ahmadian Babaki F, Rajab-Nia R Rezvani MB, et al. Antibacterial, physical and mechanical properties of flowable resin composites containing zinc oxide nanoparticles. Dent Mater 2013:29(5):495-505

21. Moszner N, Salz U. Recent developments of new components for dental adhesives and composites. Macromol Mater Eng. 2007:292(3):245-71.

22. Ren G, Hu D, Cheng EW, Vargas-Reus MA, Reip P, Allaker RP. Characterisation of copper oxide nanoparticles for antimicrobial applications. Int J Antimicrob Agents. 2009;33(6):587-90

23. Alt $V$, Bechert $T$, Steinrücke $P$, Wagener $M$, Seidel $P$, Dingeldein $E$, et al. An in vitro assessment of the antibacterial properties and cytotoxicity of nanoparticulate silver bone cement. Biomaterials. 2004;25(18):4383-91.

24. Argueta-Figueroa L, Scougall-Vilchis RJ, Morales-Luckie RA, Olea-Mejia OF. An evaluation of the antibacterial properties and shear bond strength of copper nanoparticles as a nanofiller in orthodontic adhesive. Aust Orthod J. 2015:31(1):42-8

25. Rai M, Yadav A, Gade A. Silver nanoparticles as a new generation of antimicrobials. Biotechnol Adv. 2009;27(1):76-83.

26. Kasraei S, Sami L, Hendi S, Alikhani MY, Rezaei-Soufi L, Khamverdi Z Antibacterial properties of composite resins incorporating silver and zinc oxide nanoparticles on Streptococcus mutans and Lactobacillus. Restor Dent Endod. 2014;39(2):109-14.

27. Chambers C, Stewart SB, Su B, Jenkinson HF, Sandy JR, Ireland AJ. Silver doped titanium dioxide nanoparticles as antimicrobial additives to dental polymers. Dent Mater. 2017;33(3):e115-23.

28. Mirhashemi A, Bahador A, Kassaee M, Daryakenari G, Ahmad-Akhoundi M. Sodagar A. Antimicrobial effect of nano-zinc oxide and nano-chitosan particles in dental composite used in orthodontics. J Med Bacteriol. 2015:2(3-4):1-10.

29. Abdulkareem EH, Memarzadeh K, Allaker RP, Huang J, Pratten J, Spratt D. Anti-biofilm activity of zinc oxide and hydroxyapatite nanoparticles as dental implant coating materials. J Dent. 2015;43(12):1462-9. 